OPEN ACCESS

Edited by:

Nick Verhaeghe,

Ghent University, Belgium

Reviewed by:

Aleksandra Barac,

Faculty of Medicine,

University of Belgrade,

Serbia

Tomasz Holecki,

Medical University of

Silesia, Poland

*Correspondence:

Guenka Petrova

guenka.petrova@gmail.com

Specialty section:

This article was submitted

to Health Economics,

a section of the journal

Frontiers in Public Health

Received: 29 December 2017

Accepted: 16 February 2018

Published: 05 March 2018

Citation:

Kamusheva M, Vassileva $M$, Savova A, Manova M and Petrova G

(2018) An Overview of the

Reimbursement Decision-Making

Processes in Bulgaria As a Reference

Country for the Middle-Income

European Countries.

Front. Public Health 6:61.

doi: 10.3389/fpubh.2018.00061

\section{An Overview of the Reimbursement Decision-Making Processes in Bulgaria As a Reference Country for the Middle-Income European Countries}

\author{
Maria Kamusheva ${ }^{1}$, Mariya Vassileva ${ }^{2}$, Alexandra Savova ${ }^{1,2}$, Manoela Manova $^{1,2}$ \\ and Guenka Petrova ${ }^{1 *}$
}

${ }^{1}$ Faculty of Pharmacy, Medical University of Sofia, Sofia, Bulgaria, ${ }^{2}$ National Council on Prices and Reimbursement, Sofia, Bulgaria

Background: Policy makers face a lot of challenges in the process of drug reimbursement decision-making, especially in the context of entering the market of more and more innovative medicinal products (MPs). The aim of the current study is to make an overview of the reimbursement system development and to evaluate the access of innovative medicines, which have entered the EU-market in the period 2015-2017, in Bulgaria as reference example for middle-income European country.

Methods: A literature and a legislative systematic review regarding the Bulgarian reimbursement system as well as a defining the number of available innovative reimbursed MPs in 2017 in Bulgaria was made.

Results: The reimbursement legislation in Bulgaria is quite unstable due to constant changes, which have been made, especially in the recent years. Despite this fact, the reimbursement process in Bulgaria is in accordance with the Transparency Directive. Bulgarian patients have a relatively delayed access to innovative medicines as only $5 \%$ of centrally authorized MPs in 2017 are available in the positive drug list (PDL), 16\% of all in 2016 and $18 \%$ - in 2015. This could be explained by the long procedure for their appraisal in Bulgaria: the first step is issuing an opinion by the HTA Committee, followed by negotiation of discounts between the marketing authorization holder and the National Health Insurance Fund and making a final decision by the National Council on Prices and Reimbursement (NCPR) for the inclusion into the PDL.

Conclusion: Optimization of the procedure for issuing reimbursement status for innovative MPs is needed, such as improvements in the process of conducting HTA reports and their appraisal, incorporation of adequate systems for following the effectiveness and safety of MPs in the real-world conditions, value-based pricing implementation, and increasing the financial control over the health insurance system.

Keywords: reimbursement, Bulgaria, low and middle-income Balkan countries, innovative medicines, access, affordability, positive drug list 


\section{INTRODUCTION}

The policy makers are constantly facing the challenge to find the balance between the increased patients' needs of innovative, high costly medicines and limited financial resources (1). The scarce resources and the increasing patients' needs define the need for implementation of strict pharmacoeconomic evaluations for the purposes of making the right decision.

A lot of issues still exist, notably in the middle and uppermiddle-income European countries (2). The economic situation in these countries is critical and there is an emergency need of more efficient reallocation of the resources especially in the pharmaceutical sector. Their health-care systems are not as stable as they should be due to a lot of reforms which have been made in the recent years (2). Rancic et al. concluded that the total health expenditures showed significant growth in the period 1995-2012 probably due to population aging (3). Pharmaceutical expenditures are a significant part of total health-care expenditures. For example, in Bulgaria the pharmaceutical expenditures increase every year, which leads to the annual budget deficit for National Health Insurance Fund (NHIF) (4). Therefore, more precise cost-containment measures should be applied as well as optimization of HTA usage in order to get better value for money $(2,5)$. Implementation of effective working generic policy and entering the market of biosimilar products are also possible measures (2). As Jakovljevic et al. highlighted there are some factors such as demographic crisis which could not be overcome and which is a main pharmaceutical expenditures driver in the next years (2, 6-8). Moreover, Bulgaria as the EU Member State with the lowest income per capita [only $47 \%$ of the EU average (9)] faces many challenges in ensuring the most innovative medicines for its citizens.

The aim of the current study is to make an overview of the reimbursement system development and to evaluate the access of innovative medicines, which have entered the EU-market in the period 2015-2017, in Bulgaria as reference example for middleincome European country.

\section{MATERIALS AND METHODS}

The first part of the study was a literature and a legislative systematic review regarding the implemented reimbursement system in Bulgaria for the period 2000-2017. A search was made in the official websites of Bulgarian institutions such as Ministry of Health, NHIF, National Council on Prices and Reimbursement of Medicinal Products (MPs), National Centre for Public Health and Analyses, and Bulgarian Drug Agency in order to identify the latest legislative documents and guidelines for conducting of administrative pricing and reimbursement procedures.

The second part of the study included a search of all MPs (MPs) which received marketing authorization through the centralized procedure for the period 2015-2017. A comparison of the generated list of these MPs by the website of the European Medicines Agency (EMA) and the current Bulgarian Positive Drug List (PDL) was made. Therefore, the availability of the newest medicines in Bulgaria was analyzed.

The third part of the study presents a systematic and analytical review of the identified issues in the reimbursement process in Bulgaria on the basis of the authors' point of view and officially published scientific studies.

\section{RESULTS}

\section{Reimbursement Legislation in Bulgaria}

The Health Insurance Act (1998) introduced the mandatory health insurance in Bulgaria (Figure 1) (10). According to this law NHIF was founded in 1999 as an independent public institution (11). The NHIF reimburse MPs, medical devices, dietetic foods, foods for special purposes for treatment of obligatory health insured Bulgarian citizens, as well as for hospitalized patients. For the inclusion of the medicines in the reimbursement lists a methodological approach has been developed and published in 2000, in which several crucial points were stated:

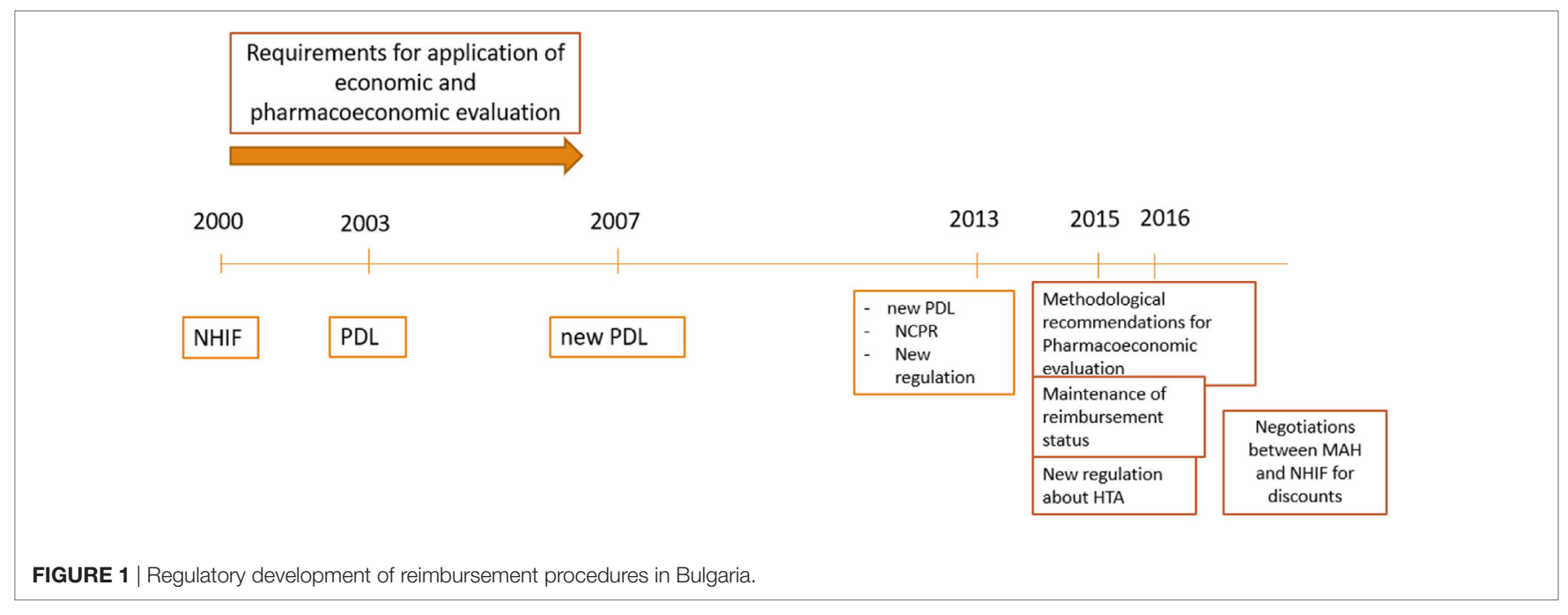


1. economic analysis should precede the pharmacoeconomic analysis;

2. economic analysis includes directs costs, due to product application; market share, prices; additional costs etc.;

3. pharmacoeconomic analysis is a comparison of the costs and consequences of the product application and its competitors (12).

The Council Decree 81 in 2003 stipulates the criteria, conditions and procedures for including MPs in the Bulgarian PDL. Three groups of MPs in PDL were defined:

A new MPs without a medicinal alternative in the clinical practice (new mechanism of action, new ATC code);

$B$ new medicines for which there is a therapeutic alternative with pharmacotherapeutic advantages (group A and B are innovative products);

C MPs with a medicinal alternative in the clinical practice (generics).

A fixed percent of the reimbursement for each MP is defined $(100,75,50$, and $25 \%)$ on the basis of its importance for disease therapy and severity of the disease.

In 2007 after the Bulgarian accession to the EU new Regulation was issued and the structure of PDL was changed: ANNEX 1: for fully or partly reimbursed medicines paid by the NHIF; ANNEX 2: medicines paid by the hospital budgets; ANNEX 3: medicines paid by the Ministry of Health budget according to Health Insurance Law; ANNEX 4: medicines for the therapy of rare diseases, HIV, and prophylactics of infections. There were no particular recommendations or guidelines for the development and presentation of the pharmacoeconomic analysis.

The pricing and reimbursement decision process were merged and delegated to one institution in 2013. The National Council on Prices and Reimbursement (NCPR) was established as responsible body for inclusion and exclusion of MPs in the PDL (PDL) and for maintenance of their reimbursement status (13). The PDL was changed and there are now three main annexes and the time for decision was shortened (60 days). All innovative medicines should receive a positive opinion by the Health Technology Assessment Committee since 2015 before issuing the final decision by the Council $(14,15)$.

Pharmacoeconomic and HTA dossiers are prepared following the officially published methodological guidelines. Science-based efficacy, safety, and pharmacoeconomic evidence should be presented in the dossier. Schematic explanation of the reimbursement procedure is shown on Figure 2.

A number of discounts are possible and their level should be negotiated between the Marketing authorization holder (MAH) and the NHIF (16):

1. mandatory discount for reimbursement of Single Source Products (new INNs) ( $>10 \%$ );

2. mandatory discount for new INN and combinations-there is no particular percentage;

3. managed entry agreement-MAH should provide additional discount when the agreed annual expenditures of the MP for each relevant year is exceeded (if the forecast values exceeded to $10 \%$ then the discount is not lower than $25 \%$; if the forecast values exceeded to $10-15 \%$ the discount is not lower than $50 \%$; if the forecast values exceeded to $15-25$ per cent then the discount is not lower than $75 \%$; if the forecast values exceeded $25 \%$ then the discount is not lower than $90 \%)$;

4. growth discount-MAH should pay back $20 \%$ of the relevant rate of growth, when the total growth is higher than $3 \%$ from the negotiated (for e.g., the expected expenditures are $100 \mathrm{mil}$ lion BGN, but the real expenditures are 110 mill BGN then the

\section{Application by MAH +}

\begin{tabular}{|c|c|c|c|c|c|}
\hline $\begin{array}{l}\text { data on clinical trials and } \\
\text { pharmacological tests }\end{array}$ & $\begin{array}{l}\text { declaration that the necessary } \\
\text { quantities will be procured }\end{array}$ & defined daily dose & $\begin{array}{l}\text { documentary proof of } \\
\text { stamp duty paid }\end{array}$ & $\begin{array}{l}\text { pharmacoeconomic } \\
\text { analysis }\end{array}$ & $\begin{array}{l}\text { copy of a contract with } \\
\text { NHIF for granting discount } \\
\text { for medicinal products }\end{array}$ \\
\hline \multicolumn{6}{|c|}{$\begin{array}{l}\text { Within } 60 \text { days the Council shall review the documents and shall take decision for maintenance of reimbursable status ( } 90 \text { days for } \\
\text { new INN) }\end{array}$} \\
\hline \multicolumn{2}{|c|}{$\begin{array}{l}\text { non-conformities and deficiencies } \rightarrow 30 \text { days for } \\
\text { corrections }\end{array}$} & \multicolumn{2}{|c|}{$\begin{array}{l}\text { A legal, medical and economic evaluation prepared by } \\
\text { experts of the specialized administration of the Council. }\end{array}$} & \multicolumn{2}{|c|}{$\begin{array}{l}\text { a rapporteur, shall prepare a summary of the expert } \\
\text { opinions and shall prepare an expert report in a standard } \\
\text { form }\end{array}$} \\
\hline \multicolumn{6}{|c|}{ Transparency Commission } \\
\hline \multicolumn{6}{|c|}{$\begin{array}{l}\text { Negative decision of the Council shall be subject to administrative appeal } \\
\text { before the Transparency Commission }\end{array}$} \\
\hline
\end{tabular}

FIGURE 2 | Procedure for inclusion of MPs in PDL. Abbreviations: MPs, medicinal products; PDL, positive drug list. 
MAH should pay back $20 \%$ of 10 million BGN). Exchange rate is $1 \mathrm{BGN}=0.51$ Euro;

5. voluntary discounts-for multiple source products; every MAH could provide voluntary additional discounts.

\section{Access and Affordability to Innovative MPs in Bulgaria}

Bulgarian patients have a relatively delayed access to innovative medicines. The percentage of innovative MPs included in the Bulgarian PDL is far below $20 \%$. The number of the newest medicines authorized through the centralized procedure by the EMA in 2017, is 83. Only three of them are reimbursed in Bulgaria and one has received a positive opinion by the HTA Committee. Logically, the number of reimbursed innovative MPs in Bulgaria, which entered the EU-market in 2015 and 2016, is higher than the following year: 18 and 16\%, respectively (Figure 3). Some innovative products even do not apply for reimbursement and only register prices for non-reimbursable marketing.

Despite the limited number of reimbursed innovative medicines, very important and promising therapies such as those for Hepatitis C, HIV, multiple myeloma, oncological conditions, etc. are ensured for all Bulgarian patients for whom there is no other option (Table 1).

\section{MPs Reimbursement Issues in Bulgaria As an Example for Middle-Income EU Country}

The financial limitations of low and middle-income countries are the main drivers for cost-containment measures introduction. In the context of medical and pharmaceutical development, the requirements to the NHIF are increasing. Therefore, more precise and regular financial control mechanisms should be implemented. Another serious problem in these countries is the lack of expertise and the limited local epidemiological data for the purposes of preparing a valuable pharmacoeconomic/ HTA dossier. Some of the issues regarding the reimbursement process in Bulgaria and the possible solutions are highlighted in Table 2.

\section{DISCUSSION}

The reimbursement policy in Bulgaria could be characterized by implementation of lots of rules for the inclusion of medicines into the PDL and a clear process of reimbursement performed by the National Council on Prices and Reimbursement (19). Despite the necessity of their further improvement, the available pharmacoeconomic and HTA guidelines give the possibility to the policy decision maker to step on a scientific basis in order to make the best possible reimbursement decision. Some problems such as lack of mechanisms for gathering effectiveness data from real-world studies, the periodic legislative changes and the lack of enough experts in the area could be highlighted. Further improvement in the legislative framework is needed in order to cope with the increasing reimbursement expenditures. Collaboration with other European countries could be useful in order to find the best solutions for the reimbursement practice in Bulgaria $(20,21)$. The process of development and improvement of reimbursement policy is slower, but it could ensure more options for providing innovative medicines to the population $(22,23)$ as it is the case in other Balkan countries such as Greece $(2,24)$, Croatia (25), Bosna and Herzegovina, and Republic of Serbia (26). Several crucial changes are proposed in Polish reimbursement system. One of these changes aims to create an innovative reimbursement budget, which will provide

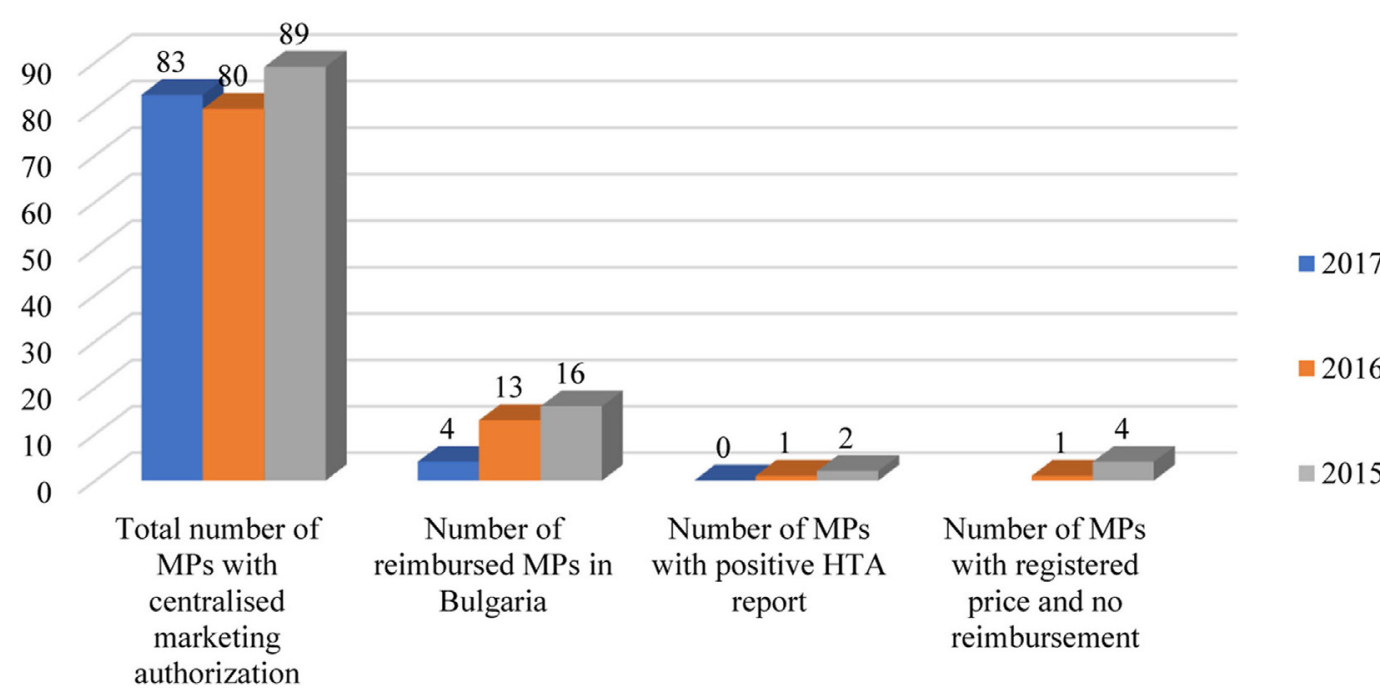

FIGURE 3 | Reimbursement status of MPs in Bulgaria authorized through centralized procedure in the EU. Abbreviations: MA, marketing authorization; MPs, medicinal products; HTA, health technology assessment. 
TABLE 1 | Medicinal products with centralized marketing authorization, which are available in Bulgaria.

\begin{tabular}{|c|c|c|c|c|c|}
\hline Active Substance & $\begin{array}{l}\text { ATC } \\
\text { code }\end{array}$ & $\begin{array}{l}\text { Authorization } \\
\text { date }\end{array}$ & Indication/ICD & $\begin{array}{l}\text { Condition Approval/ } \\
\text { Exceptional Circumstance/ } \\
\text { Orphan/Generic/Biosimilar }\end{array}$ & $\begin{array}{l}\text { Reimbursement } \\
\text { status in Bulgaria, } \\
\text { Year }\end{array}$ \\
\hline Blinatumomab & L01XC & 23/11/2015 & $\begin{array}{l}\text { ICD C91.0 } \\
\text { Philadelphia chromosome negative relapsed or } \\
\text { refractory B-precursor acute lymphoblastic leukemia } \\
\text { (ALL) }\end{array}$ & Conditional approval; Orphan & $\begin{array}{l}\text { Positive HTA; } \\
01.2017\end{array}$ \\
\hline $\begin{array}{l}\text { Cobimetinib } \\
\text { hemifumarate }\end{array}$ & L01XE38 & $20 / 11 / 2015$ & $\begin{array}{l}\text { In combination with vemurafenib for the treatment } \\
\text { of adult patients with unresectable or metastatic } \\
\text { melanoma with a BRAF V600 mutation }\end{array}$ & & $\begin{array}{l}\text { Price registration; } \\
\text { not reimbursed }\end{array}$ \\
\hline Efmoroctocog alfa & B02BD02 & $19 / 11 / 2015$ & $\begin{array}{l}\text { ICD: D66 } \\
\text { Treatment and prophylaxis of bleeding in patients with } \\
\text { hemophilia A }\end{array}$ & & Reimbursed, 2017 \\
\hline $\begin{array}{l}\text { Elvitegravir/cobicistat/ } \\
\text { emtricitabine/tenofovir } \\
\text { alafenamide }\end{array}$ & J05AR & $19 / 11 / 2015$ & $\begin{array}{l}\text { Treatment of adults and adolescents infected with } \\
\text { human immunodeficiency virus } 1(\mathrm{HIV}-1) \text { without any } \\
\text { known mutations associated with resistance to the } \\
\text { integrase inhibitor class, emtricitabine or tenofovir }\end{array}$ & & $\begin{array}{l}\text { Price registration; } \\
\text { not reimbursed }\end{array}$ \\
\hline Sacubitril/valsartan & C09DX04 & 19/11/2015 & $\begin{array}{l}\text { ICD: } 150.0 ; 150.1 \\
\text { For treatment of symptomatic chronic heart failure with } \\
\text { reduced ejection fraction }\end{array}$ & & Reimbursed, 2016 \\
\hline Carfilzomib & L01XX45 & $19 / 11 / 2015$ & $\begin{array}{l}\text { ICD: C90.0 } \\
\text { Multiple myeloma }\end{array}$ & Orphan & Reimbursed, 2017 \\
\hline Aripiprazole & N05AX12 & $16 / 11 / 2015$ & $\begin{array}{l}\text { ICD: F20.0, F20.1, F20.5, F20.6, F30.0, F30.1, F31.0, } \\
\text { F31.1, F31.2, F31.7 } \\
\text { Schizophrenia; moderate to severe manic episodes in } \\
\text { Bipolar I Disorder; prevention of a new manic episode }\end{array}$ & Generic & Reimbursed, 2016 \\
\hline $\begin{array}{l}\text { Pemetrexed disodium } \\
\text { hemipentahydrate }\end{array}$ & L01BA04 & $18 / 09 / 2015$ & Malignant pleural mesothelioma & Generic & Reimbursed, 2017 \\
\hline Pregabalin & N03AX16 & $28 / 08 / 2015$ & $\begin{array}{l}\text { ICD: G40.6, G40.7 } \\
\text { Epilepsy; generalized anxiety disorder }\end{array}$ & Generic & Reimbursed, 2016 \\
\hline Aripiprazole & N05AX12 & 20/08/2015 & $\begin{array}{l}\text { ICD: F20.0, F20.1, F20.5, F20.6, F30.0, F30.1, F31.0, } \\
\text { F31.1, F31.2, F31.7 } \\
\text { Schizophrenia in adults and in adolescents aged } \\
15 \text { years and older. } \\
\text { Moderate to severe manic episodes in Bipolar I } \\
\text { Disorder and for the prevention of a new manic } \\
\text { episode }\end{array}$ & Generic & Reimbursed, 2016 \\
\hline Bortezomib & L01XX32 & $20 / 07 / 2015$ & $\begin{array}{l}\text { ICD: C90.0, C90.1, C90.2 } \\
\text { Progressive multiple myeloma }\end{array}$ & Generic & Reimbursed, 2016 \\
\hline Evolocumab & C10 & $17 / 07 / 2015$ & $\begin{array}{l}\text { ICD: E78.0 } \\
\text { Hypercholesterolemia and mixed dyslipidaemia }\end{array}$ & & Reimbursed, 2016 \\
\hline Nivolumab & L01XC & $19 / 06 / 2015$ & $\begin{array}{l}\text { ICD: C43.0, C43.1, C43.2, C43.3, C43.4, C43.5, } \\
\text { C43.6, C43.7, C43.8, C43.9 } \\
\text { Advanced (unresectable or metastatic) melanoma } \\
\text { Non-small cell lung cancer (NSCLC) } \\
\text { Renal cell carcinoma (RCC) } \\
\text { Classical hodgkin lymphoma (cHL) } \\
\text { Squamous cell cancer of the head and neck (SCCHN) } \\
\text { Urothelial carcinoma }\end{array}$ & & Reimbursed, 2018 \\
\hline Edoxaban tosylate & B01 & $19 / 06 / 2015$ & $\begin{array}{l}\text { ICD: } 126.0,148,169.3,169.4,180.1,180.2 \\
\text { Prevention of stroke and systemic embolism in adult } \\
\text { patients with nonvalvular atrial fibrillation (NVAF) with } \\
\text { one or more risk factors }\end{array}$ & & Reimbursed, 2017 \\
\hline $\begin{array}{l}\text { Empagliflozin/ } \\
\text { metformin }\end{array}$ & A10BD20 & 27/05/2015 & $\begin{array}{l}\text { ICD: E11.2, E11.3, E11.4, E11.5, E11.9 } \\
\text { Type } 2 \text { diabetes mellitus }\end{array}$ & & Reimbursed, 2016 \\
\hline $\begin{array}{l}\text { Netupitant/ } \\
\text { palonosetron } \\
\text { hydrochloride }\end{array}$ & A04AA & $27 / 05 / 2015$ & Prevention of acute and delayed nausea and vomiting & & $\begin{array}{l}\text { Positive HTA; } \\
08.2017\end{array}$ \\
\hline
\end{tabular}


TABLE 1 | Continued

\begin{tabular}{|c|c|c|c|c|c|}
\hline Active Substance & $\begin{array}{l}\text { ATC } \\
\text { code }\end{array}$ & $\begin{array}{l}\text { Authorization } \\
\text { date }\end{array}$ & Indication/ICD & $\begin{array}{l}\text { Condition Approval/ } \\
\text { Exceptional Circumstance/ } \\
\text { Orphan/Generic/Biosimilar }\end{array}$ & $\begin{array}{l}\text { Reimbursement } \\
\text { status in Bulgaria, } \\
\text { Year }\end{array}$ \\
\hline Ceritinib & L01XE & 06/05/2015 & $\begin{array}{l}\text { Anaplastic lymphoma kinase (ALK) positive advanced } \\
\text { non-small cell lung cancer (NSCLC) }\end{array}$ & & $\begin{array}{l}\text { price registration; } \\
\text { not reimbursed }\end{array}$ \\
\hline $\begin{array}{l}\text { Bupropion } \\
\text { hydrochloride/ } \\
\text { naltrexone } \\
\text { hydrochloride }\end{array}$ & A08AA & 26/03/2015 & Management of weight in adult patients (18 years) & & $\begin{array}{l}\text { price registration; } \\
\text { not reimbursed }\end{array}$ \\
\hline Secukinumab & L04AC10 & $15 / 01 / 2015$ & $\begin{array}{l}\text { ICD: L40.0, M07.1, M07.2, M07.3, M45.0, M45.1, } \\
\text { M45.2, M45.3, M45.4, M45.5, M45.6, M45.7, M45.8 } \\
\text { Moderate to severe plaque psoriasis } \\
\text { Psoriatic arthritis } \\
\text { Ankylosing spondylitis }\end{array}$ & & Reimbursed, 2016 \\
\hline Dasabuvir sodium & J05AX16 & $15 / 01 / 2015$ & $\begin{array}{l}\text { ICD: B18.2, K74.0, K74.6 } \\
\text { Treatment of chronic hepatitis C (CHC) in adults } \\
\text { For hepatitis C virus (HCV) genotype specific activity }\end{array}$ & & Reimbursed, 2015 \\
\hline Nintedanib & L01XE & $15 / 01 / 2015$ & $\begin{array}{l}\text { ICD: J84.1 } \\
\text { Idiopathic pulmonary fibrosis (IPF) }\end{array}$ & & Reimbursed, 2018 \\
\hline $\begin{array}{l}\text { Ombitasvir/ } \\
\text { paritaprevir/ritonavir }\end{array}$ & & $15 / 01 / 2015$ & $\begin{array}{l}\text { ICD: B18.2, K74.0, K74.6 } \\
\text { Chronic hepatitis C (CHC) in adults } \\
\text { For hepatitis C virus ( } \mathrm{HCV} \text { ) genotype specific activity }\end{array}$ & & Reimbursed, 2015 \\
\hline $\begin{array}{l}\text { Pemetrexed diacid } \\
\text { monohydrate }\end{array}$ & L01BA04 & 18/01/2016 & $\begin{array}{l}\text { Malignant pleural mesothelioma } \\
\text { Non-small cell lung cancer }\end{array}$ & & Reimbursed, 2016 \\
\hline Osimertinib mesylate & L01XE & 02/02/2016 & $\begin{array}{l}\text { ICD: C34.0, C34.1, C34.2, C34.3, C34.8, C34.9 } \\
\text { Locally advanced or metastatic epidermal growth } \\
\text { factor receptor (EGFR) T790M mutation-positive non- } \\
\text { small-cell lung cancer (NSCLC) }\end{array}$ & & Reimbursed, 2018 \\
\hline Tenofovir disoproxil & J05AF07 & 08/12/2016 & $\begin{array}{l}\text { ICD: B18.1, K74.0, K74.6 } \\
\text { HIV-1 infection } \\
\text { Hepatitis B infection }\end{array}$ & Generic & Reimbursed, 2017 \\
\hline Venetoclax & L01XX52 & 05/12/2016 & $\begin{array}{l}\text { ICD: C91.1 } \\
\text { Chronic lymphocytic leukemia (CLL) in the presence of } \\
\text { 17p deletion or TP53 mutation }\end{array}$ & Conditional approval/orphan & Reimbursed, 2018 \\
\hline $\begin{array}{l}\text { Etelcalcetide } \\
\text { hydrochloride }\end{array}$ & H05BX04 & $11 / 11 / 2016$ & $\begin{array}{l}\text { Secondary hyperparathyroidism (SHPT) in adult } \\
\text { patients with chronic kidney disease (CKD) on } \\
\text { hemodialysis therapy }\end{array}$ & & Reimbursed, 2017 \\
\hline Palbociclib & L01XE33 & 09/11/2016 & $\begin{array}{l}\text { ICD: C50.0, C50.1, C50.2, C50.3, C50.4, C50.5, } \\
\text { C50.6, C50.8, C50.9 } \\
\text { Hormone receptor (HR) positive, human epidermal } \\
\text { growth factor receptor } 2 \text { (HER2) negative locally } \\
\text { advanced or metastatic breast cancer }\end{array}$ & & Reimbursed, 2018 \\
\hline $\begin{array}{l}\text { Tenofovir disoproxil } \\
\text { phosphate }\end{array}$ & J05AF07 & 15/09/2016 & $\begin{array}{l}\text { ICD: B18.1, K74.0, K74.6 } \\
\text { HIV-1 infection } \\
\text { Hepatitis B infection }\end{array}$ & Generic & Reimbursed, 2017 \\
\hline $\begin{array}{l}\text { Salmeterol xinafoate/ } \\
\text { fluticasone propionate }\end{array}$ & R03AK06 & 18/08/2016 & $\begin{array}{l}\text { ICD: J44.8, J45.0, J45.1 } \\
\text { Asthma } \\
\text { Chronic obstructive pulmonary disease (COPD) }\end{array}$ & & Reimbursed, 2017 \\
\hline Elbasvir/grazoprevir & J05A & 22/07/2016 & $\begin{array}{l}\text { ICD: B18.2, K74.0, } \mathrm{K} 74.6 \\
\text { Chronic hepatitis } \mathrm{C}(\mathrm{CHC}) \text { in adults }\end{array}$ & & Reimbursed, 2016 \\
\hline $\begin{array}{l}\text { Emtricitabine/rilpivirine } \\
\text { hydrochloride/ } \\
\text { tenofovir alafenamide }\end{array}$ & J05AR19 & 21/06/2016 & Human immunodeficiency virus 1 (HIV-1) & & $\begin{array}{l}\text { Positive HTA; } \\
08.2017\end{array}$ \\
\hline Sacubitril/valsartan & C09DX04 & 26/05/2016 & $\begin{array}{l}\text { ICD: } 150.0,150.1 \\
\text { Symptomatic chronic heart failure with reduced } \\
\text { ejection fraction }\end{array}$ & & Reimbursed, 2016 \\
\hline $\begin{array}{l}\text { Trifluridine/tipiracil } \\
\text { hydrochloride }\end{array}$ & L01BC & 25/04/2016 & Metastatic colorectal cancer (CRC) & & $\begin{array}{l}\text { price registration; } \\
\text { not reimbursed }\end{array}$ \\
\hline
\end{tabular}


TABLE 1 | Continued

\begin{tabular}{|c|c|c|c|c|c|}
\hline Active Substance & $\begin{array}{l}\text { ATC } \\
\text { code }\end{array}$ & $\begin{array}{l}\text { Authorization } \\
\text { date }\end{array}$ & Indication/ICD & $\begin{array}{l}\text { Condition Approval/ } \\
\text { Exceptional Circumstance/ } \\
\text { Orphan/Generic/Biosimilar }\end{array}$ & $\begin{array}{l}\text { Reimbursement } \\
\text { status in Bulgaria, } \\
\text { Year }\end{array}$ \\
\hline $\begin{array}{l}\text { Emtricitabine/tenofovir } \\
\text { alafenamide }\end{array}$ & J05AR17 & $21 / 04 / 2016$ & $\begin{array}{l}\text { ICD: B20.0, B20.1, B20.2, B20.3, B20.4, B20.5, } \\
\text { B20.6, B20.7, B20.8, B20.9, B21.0, B21.2, B21.3, } \\
\text { B21.7, B21.8, B21.9, B22.0, B22.1, B22.2, B22.7, } \\
\text { B23.0, B23.1, B23.2, B23.8, B24, Z21 } \\
\text { Human immunodeficiency virus type } 1 \text { (HIV-1) }\end{array}$ & & Reimbursed, 2017 \\
\hline $\begin{array}{l}\text { Amlodipine besilate/ } \\
\text { valsartan }\end{array}$ & C09DB01 & 22/03/2016 & $\begin{array}{l}\text { ICD: I10, I11.0, I11.9, I12.0, I12.9, I13.0, I13.1, I13.2 } \\
\text { Essential hypertension }\end{array}$ & Generic & Reimbursed, 2017 \\
\hline Octocog alfa & B02BD02 & 18/02/2016 & $\begin{array}{l}\text { ICD: D66 } \\
\text { Treatment and prophylaxis of bleeding in patients with } \\
\text { hemophilia A (congenital factor VIII deficiency) }\end{array}$ & & Reimbursed, 2017 \\
\hline Rituximab & L01XC02 & $13 / 07 / 2017$ & $\begin{array}{l}\text { ICD: C82.0, C82.1, C82.2, C82.7, C82.9, C83.2, } \\
\text { C83.3, C83.9, C91.1, M31.3, M31.9 } \\
\text { Non-Hodgkins lymphoma (NHL) } \\
\text { Follicular lymphoma patients } \\
\text { CD20 positive diffuse large B cell non- } \\
\text { Hodgkins lymphoma in combination with CHOP } \\
\text { (cyclophosphamide, doxorubicin, vincristine, } \\
\text { prednisolone) chemotherapy } \\
\text { Granulomatosis with polyangiitis and microscopic } \\
\text { polyangiitis } \\
\text { Induction of remission in adult patients with severe, } \\
\text { active granulomatosis with polyangiitis (Wegeners) } \\
\text { (GPA) and microscopic polyangiitis (MPA) }\end{array}$ & Biosimilar & Reimbursed, 2017 \\
\hline Edoxaban tosylate & B01AF03 & 20/04/2017 & $\begin{array}{l}\text { ICD: I26.0, I48, I69.3, I69.4, I80.1, } 180.2 \\
\text { Prevention of stroke and systemic embolism } \\
\text { Deep vein thrombosis (DVT) and pulmonary embolism } \\
\text { (PE), and prevention of recurrent DVT and PE in adults }\end{array}$ & & Reimbursed, 2017 \\
\hline Tofacitinib citrate & L04AA29 & 22/03/2017 & $\begin{array}{l}\text { ICD: M05.0, M05.1, M05.3, M05.8 } \\
\text { Moderate to severe active rheumatoid arthritis (RA) }\end{array}$ & & Reimbursed, 2018 \\
\hline Darunavir & J05AE10 & 04/01/2017 & Human immunodeficiency virus (HIV-1) infection & Generic & Reimbursed, 2017 \\
\hline
\end{tabular}

ATC code, Anatomical Therapeutic Chemical Classification System; ICD, International Classification of Diseases.

funding for reimbursement of innovative products developed by manufacturers with research and development activities with considerable impact on the Polish economy (27). Therefore, the patient access in Poland to innovative therapies could be significantly improved.

Our study confirms that the patient access to innovative medicines from the moment of their marketing authorization is delayed. The number of reimbursed innovative medicines as a percent of the centrally authorized by EMA is far below $20 \%$ which confirms some extent of limitations in the patient access. Similar results are presented by Inotai et al. for the patient access to original biologics and biosimilar in Central and Eastern European countries (CEE countries). The authors explain the results with the current implemented biosimilar policies in these countries (28), which means that some improvement in the local legislation is needed. Significant variations exist in uptake of biosimilars in Europe, which could be overcome with implementation of specific procedures and measures (29). While Western Balkan countries has proved through the years that are capable to ensure reimbursed medicines for patients with non-communicable diseases with some exceptions (30), there is still gaps in the knowledge about the patients access to innovative medicines in these countries. Study published in
2017 highlighted the large disparities in access to innovative therapy for metastatic melanoma among the European countries mostly in the Eastern European region (31). The Romanian HTA system implements criteria focused more on the costs and, therefore, it raises a barrier for the innovative medicines in the country (32).

The regulatory bodies especially in CEE countries are pressured in order to ensure new medicines (orphan MPs, innovative biological products, etc.) for severe life-threatening conditions with no available alternative (33). The budget constraints are inevitable, especially in the low- and middle-income countries. The policy makers are trying to balance in the context of deficit resources adopting various approaches. Performance based managed entry agreements for pharmaceuticals is a possible option which is partly applied in Bulgaria. Reassessment of treatments after their inclusion in the reimbursement lists gives a guarantee for collecting of more valuable evidence for effectiveness and cost-effectiveness of the new medicine (34). So, the public fund will be able to stop financing technologies with no proven value in the post reimbursement period. The crucial evidence, which should be taken into account when a reimbursement decision is made, is whether the new medicine brings additional benefits for those patients with no available alternative (23). 
TABLE 2 | Reimbursement issues in low and middle-income countries and possible solutions.

\begin{tabular}{|c|c|}
\hline $\begin{array}{l}\text { Reimbursement process } \\
\text { issues }\end{array}$ & Possible solutions \\
\hline $\begin{array}{l}\text { Financial restrictions (limited } \\
\text { budgets) }\end{array}$ & $\begin{array}{l}\text { - Improvement of the collection of health } \\
\text { contributions; } \\
\text { - Better financial control and monitoring of } \\
\text { pharmaceutical expenditures (17); } \\
\text { - Improved application of the economic } \\
\text { evaluations for the purposes of more efficient } \\
\text { reallocation of the resources; } \\
\text { - Differentiation of separate budgets for } \\
\text { specific group of medicines [for e.g., orphan } \\
\text { medicinal products (MPs)]. }\end{array}$ \\
\hline Lack of expertise (18) & $\begin{array}{l}\text { - Providing of educational programs and } \\
\text { continuing education for the government } \\
\text { employees; } \\
\text { - International collaboration. }\end{array}$ \\
\hline $\begin{array}{l}\text { Improvement in } \\
\text { pharmacoeconomic guideline/ } \\
\text { HTA guideline }\end{array}$ & $\begin{array}{l}\text { - Taking into consideration the latest } \\
\text { pharmacoeconomic studies and their } \\
\text { implementation into the practice; } \\
\text { - Differentiation of the discount levels for both } \\
\text { cost and results; } \\
\text { - Definition of separate ICER thresholds } \\
\text { regarding the type of evaluated MP; } \\
\text { - Implementation of multicriteria decision } \\
\text { analysis for some specific groups of MPs. }\end{array}$ \\
\hline $\begin{array}{l}\text { Lack of systems for tracking } \\
\text { and assessment of the } \\
\text { effectiveness of the MPs }\end{array}$ & $\begin{array}{l}\text { - Dialog between the information technology } \\
\text { companies, pharmaceutical industry and } \\
\text { health-care policy makers for creation of a } \\
\text { unified common information system; } \\
\text { - Development and maintenance of patients } \\
\text { registries; } \\
\text { - Involvement of non-profit patient organization } \\
\text { in the HTA process. }\end{array}$ \\
\hline
\end{tabular}

Strength of the current study is that it represents the development of Bulgarian reimbursement legislation since its formation in 2000 to these days. This review could be used for the purposes

\section{REFERENCES}

1. Pharmaceutical regulation in 15 European countries. Review. Health Systems in Transition (2016) 18(5). Available from: http://apps.who.int/medicinedocs/ documents/s23163en/s23163en.pdf

2. Pejcic A, Jakovljevic M. Pharmaceutical expenditure dynamics in the Balkan countries. JMed Econ (2017) 20(10):1013-7. doi:10.1080/13696998.2017. 1333514

3. Rancic N, Kovacevic A, Dragojevic-Simic V. Long-term health expenditure changes in selected Balkan countries. Front Public Health (2015) 3:152. doi:10.3389/fpubh.2015.00152

4. Iskrov G, Stefanov R. Prospects of risk-sharing agreements for innovative therapies in a context of deficit spending in Bulgaria. Front Public Health (2015) 3:64. doi:10.3389/fpubh.2015.00064

5. Vlãdescu C, Scîntee SG, Olsavszky V, Hernández-Quevedo C, Sagan A. Romania: health system review. Health Syst Transit (2016) 18(4):1-170.

6. Jakovljevic MB, Milovanovic O. Growing burden of non-communicable diseases in the emerging health markets: the case of BRICS. Front Public Health (2015) 3:65. doi:10.3389/fpubh.2015.00065

7. Jakovljevic MB, Vukovic M, Fontanesi J. Life expectancy and health expenditure evolution in Eastern Europe-DiD and DEA analysis. Expert Rev Pharmacoecon Outcomes Res (2016) 16:537-46. doi:10.1586/14737167.2016. 1125293 of making more valuable and evidence based decisions for further reforms in the system. As an example of a middle-income Balkan country, the case with Bulgarian reimbursement system could be used as a model for other Balkan countries, which are economically similar to Bulgaria and which are characterized with similar pricing and reimbursement requirements (35). To the best of our knowledge, this is the first study, which makes an attempt to present the access of Bulgarian patients to reimbursed innovative therapies, which received marketing authorization through the centralized procedure in the $\mathrm{EU}$, and to give some recommendations for improvement of the reimbursement decision about these medicines. Further studies could focus more on the real financial burden of the innovative therapies.

\section{CONCLUSION}

Optimization of the procedure for issuing reimbursement status for innovative MPs is needed especially in the Balkan countries, where lots of issues exist. Improvements in the process of conducting HTA reports and their appraisal, incorporation of adequate systems for following the effectiveness and safety of MPs in the real-world conditions, value-based pricing implementation and increasing the financial control over the health insurance system could be some of the possible solutions. It is crucial the level of expertise in these countries to be enhanced through accreditation of shared master Health Technology Assessment programs. Shared experience among Balkan countries could provide additional valuable information regarding economic evaluation and appropriate reimbursement mechanisms for innovative medicines.

\section{AUTHOR CONTRIBUTIONS}

All the authors have provided valuable contributions to the manuscript.

8. Jakovljevic M, Laaser U. Population aging from 1950 to 2010 in seventeen transitional countries in the wider region of South Eastern Europe. SEEJPH (2015) 3:1-12. doi:10.4119/UNIBI/SEEJPH-2015-49

9. The World Bank in Bulgaria, Overview (2017). Available from: http://www. worldbank.org/en/country/bulgaria/overview

10. National Peoples' Assembly. The Health Insurance Act. Governmental Newspaper. (1998). 70; last amended Gov, Newspaper 2009; 101.

11. National Health Insurance Fund (2009-2018). Available from: www.nhif.bg

12. Petrova G, Getov I. Methodological approach for economic and/or pharmacoeconomic assessment of the drugs (with $\mathrm{H} 2$-blokers practical example). Soc Med (2000) 1:37-40.

13. National Peoples' Assembly. Law on the Medicinal Products in Human Medicine. (2007). 31, last amendment 2015; 48.

14. Ministry Council. Regulation on Conditions and Rules for Regulating and Registering the Prices of Medicinal Products - Amend. (2013). Govern. Newspaper 40/ 30 April.

15. Ministry of Health. Regulation for the Conditions and Order for Performing a Health Technology Assessment. (2015). Gov.

16. Ministry of Health. Regulation 10/2009 on the Terms, Rules for Reimbursement of Medicines, Medical Devices etc. by NHIF. (2009). 24 p. Gov. Newsp.

17. Benisheva-Dimitrova T, Sidjimova D, Cherneva D, Kralimarkov N. Pricing, reimbursement, and health technology assessment of medicinal products in Bulgaria. Int J Technol Assess Health Care (2017) 33(3):365-70. doi:10.1017/ S0266462317000551 
18. Danko D, Petrova G. Health technology assessment in the Balkans: opportunities for a balanced drug assessment system. Biotechnol Biotechnol Equip (2014) 28(6):1181-9. doi:10.1080/13102818.2014.978636

19. Petrova G, Benisheva T, Ivanova A. Pharmacoeconomics and the new Bulgarian positive list. Regul Aff J (2005) 16(3):175-9.

20. Seiter A. Pharmaceutical policy challenges in Central and Eastern Europe. Eurohealth (2010) 14(1):30-2.

21. García-Mochón L, Espín Balbino J, Olry de Labry Lima A, Caro Martinez A, Martin Ruiz E, Pérez Velasco R. HTA and decision-making processes in Central, Eastern and South Eastern Europe: results from a survey. Health Policy (2017). doi:10.1016/j.healthpol.2017.03.010

22. Tesar T, Hloska A, Wawruch M, Lehocka L, Snopkova M, Masarykova L. Introduction of health technology assessment for medicines in Slovakia. Int J Technol Assess Health Care (2017) 33:1. doi:10.1017/S026646231700006X

23. Zlatareva A. Analysis of the reimbursement policy in Central and Eastern European Countries - the policy of Poland, Romania, Hungary and the Czech Republic, PART II. World J Pharm Pharm Sci (2015) 4(9):64-76.

24. European Commission. State of Health in the EU Greece Country Health Profile. Paris/Brussels: OECD Publishing/European Observatory on Health Systems and Policies (2017).

25. Huic M, Tandara Hacek R, Svajger I. Health technology assessment in Central, Eastern, and South European countries: Croatia. Int J Technol Assess Health Care (2017) 33(3):376-83. doi:10.1017/S026646231700054X

26. Guzvic V, Catic T, Kostic M. Health technology assessment in Central-Eastern and South Europe countries: Bosnia and Herzegovina. Int J Technol Assess Health Care (2017) 33(3):390-5. doi:10.1017/S0266462317000058

27. Badora K, Caban A, Rémuzat C, Dussart C, Toumi M. Proposed changes to the reimbursement of pharmaceuticals and medical devices in Poland and their impact on market access and the pharmaceutical industry. J Mark Access Health Policy (2017) 5:1-11. doi:10.1080/20016689.2017.1381544

28. Inotai A, Csanadi M, Petrova G, Dimitrova M, Bochenek T, Tesar T, et al. Patient access, unmet medical need, expected benefits, and concerns related to the utilisation of biosimilars in Eastern European countries: a survey of experts. Biomed Res Int (2018). doi:10.1155/2018/9597362 Article ID 9597362, 9 pages,
29. Moorkens E, Vulto AG, Huys I, Dylst P, Godman B, Keuerleber S, et al. Policies for biosimilar uptake in Europe: an overview. PLoS One (2017) 12(12):e0190147. doi:10.1371/journal.pone.0190147

30. Pekez-Pavlisko T, Racic M, Kusmuk S. Medicine availability and prescribing policy for non-communicable diseases in the Western Balkan countries. Front Public Health (2017) 5:295. doi:10.3389/fpubh.2017.00295

31. Kandolf Sekulovic L, Peris K, Hauschild A, Stratigos A, Grob JJ, Nathan P, et al. More than 5000 patients with metastatic melanoma in Europe per year do not have access to recommended first-line innovative treatments. Eur J Cancer (2017) 75:313-22. doi:10.1016/j.ejca.2017.01.012

32. Chiriac ND, Radu PC, Mazilu MA. Access gap to innovative treatments in Romania. Value Health (2017) 20:A690. doi:10.1016/j.jval.2017.08.1755

33. Kamusheva M, Tachkov K, Petrova G, Savova A, Manova M. Orphan medicinal products' access to the Bulgarian pharmaceutical market - challenges and obstacles. Expert Opin Orphan Drugs (2018) 6(2):95-104. doi:10.1080/21678 707.2018.1421063

34. Paris V, Slawomirski L, Colbert A, Delaunay N, Oderkirk J. New Health Technologies Managing Access, Value and Sustainability. Paris: OECD Publishing (2017). Available from: http://www.keepeek.com/Digital-AssetManagement/oecd/social-issues-migration-health/managing-newtechnologies-in-health-care_9789264266438-en\#page17

35. Kawalec P, Stawowczyk E, Tesar T, Skoupa J, Turcu-Stiolica A, Dimitrova M, et al. Pricing and reimbursement of biosimilars in Central and Eastern European countries. Front Pharmacol (2017) 8:288. doi:10.3389/fphar.2017.00288

Conflict of Interest Statement: The authors certify that they do not have any conflict of interest to declare regarding the current study.

Copyright (c) 2018 Kamusheva, Vassileva, Savova, Manova and Petrova. This is an open-access article distributed under the terms of the Creative Commons Attribution License (CC BY). The use, distribution or reproduction in other forums is permitted, provided the original author(s) and the copyright owner are credited and that the original publication in this journal is cited, in accordance with accepted academic practice. No use, distribution or reproduction is permitted which does not comply with these terms. 